\title{
Teredinibacter turnerae gen. nov., sp. nov., a dinitrogen-fixing, cellulolytic, endosymbiotic $\gamma$-proteobacterium isolated from the gills of wood-boring molluscs (Bivalvia: Teredinidae)
}

\author{
1 Department of \\ Biochemistry, \\ Microbiology, and \\ Molecular Biology, \\ University of Maine, \\ 5735 Hitchner Hall, Orono, \\ ME 04469-5735, USA \\ 2 Woods Hole \\ Oceanographic Institution, \\ Woods Hole, MA 02543, \\ USA
}

\author{
Daniel L. Distel, ${ }^{1}$ Wendy Morrill, ${ }^{1}$ Noelle MacLaren-Toussaint, ${ }^{1}$ \\ Dianna Franks ${ }^{2}$ and John Waterbury ${ }^{2}$ \\ Author for correspondence: Daniel L. Distel. Tel: +1 207581 2824. Fax: + 12075812801. \\ e-mail: distel@maine.edu
}

\begin{abstract}
A cellulolytic, dinitrogen-fixing bacterium isolated from the gill tissue of a wood-boring mollusc (shipworm) Lyrodus pedicellatus of the bivalve family Teredinidae and 58 additional strains with similar properties, isolated from gills of 24 bivalve species representing 9 of 14 genera of Teredinidae, are described. The cells are Gram-negative, rigid, rods (0.4-0.6 $\times 3-6 \mu \mathrm{m})$ that bear a single polar flagellum. All isolates are capable of chemoheterotrophic growth in a simple mineral medium supplemented with cellulose as a sole source of carbon and energy. Xylan, pectin, carboxymethylcellulose, cellobiose and a variety of sugars and organic acids also support growth. Growth requires addition of combined nitrogen when cultures are vigorously aerated, but all isolates fix dinitrogen under microaerobic conditions. The $\mathrm{pH}$, temperature and salinity optima for growth were determined for six isolates and are approximately 8.5, 30-35 ${ }^{\circ} \mathrm{C}$ and $0.3 \mathrm{M} \mathrm{NaCl}$ respectively. The isolates are marine. In addition to $\mathrm{NaCl}$, growth requires elevated concentrations of $\mathrm{Ca}^{2+}$ and $\mathrm{Mg}^{2+}$ that reflect the chemistry of seawater. The DNA G+C content ranged from 49 to $51 \mathrm{~mol} \%$. Four isolates were identical with respect to small-subunit rRNA sequence over 891 positions compared and fall within a unique clade in the $\gamma$-subclass of the Proteobacteria. Based on morphological, physiological and phylogenetic characteristics and specific symbiotic association with teredinid bivalves, a new genus and species, Teredinibacter turnerae gen. nov.,

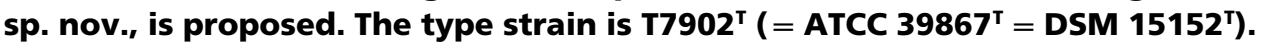

Keywords: Teredinidae, bivalvia, shipworms, symbiont, 16S rRNA phylogeny

\section{INTRODUCTION}

Endosymbiotic bacteria are found within the gills of several hundred bivalve species. These species are confined to a relatively small but extremely diverse selection of bivalve taxa, including all examined species within the families Teredinidae, Solemyidae, Vesicomyidae and Lucinidae, most Thyasiridae, and all examined members of the subfamilies Xylophagainae

A table of strain data and a full phylogenetic tree are available as supplementary data in IJSEM Online (http://ijs.sgmjournals.org).

The GenBank/EMBL/DDBJ accession number for the 16S rDNA sequence of strain $\mathrm{T} 7902^{\top}$ is AY028398. (family Pholadidae) and Bathymodiolinae (family Mytilidae) (Fisher, 1990).

Much has been inferred about the physiology and phylogeny of bivalve gill endosymbionts based on molecular and biochemical investigations. For example, symbionts of Solemyidae, Vesicomyidae, Lucinidae and Thyasiridae have been determined to be sulfur-oxidizing chemolithoautotrophs, while those of Bathymodiolinae are either chemolithoautotrophs or methanotrophs (Fisher, 1990). Carbon, fixed by these symbionts, provides an important contribution to the host's diet. Symbionts of Teredinidae and Xylophagainae, on the other hand, play a different role in host nutrition. These symbionts are thought to provide cellulolytic enzymes that facilitate the digestion of 
wood by their hosts (Distel \& Roberts, 1997; Greene, 1994; Waterbury et al., 1983).

The shipworm isolates reported by Waterbury et al. (1983) and formally described here, however, are the only gill-born bivalve endosymbionts yet cultivated, characterized, or named. The shipworm isolate $\mathrm{T} 7902^{\mathrm{T}}$ has been confirmed by molecular methods (fluorescent in situ hybridization) to be a symbiotic inhabitant of gill tissues of the shipworm Lyrodus pedicellatus (Distel et al., 1991) and the morphology and ultrastructure of this symbiosis has been described. Growth characteristics (Greene \& Freer, 1986), cellulolytic and proteolytic activities (Greene et al., 1988; Imam et al., 1993), and cellulose binding properties (Imam et al., 1990) have also been described for strain T8201, isolated from Psiloteredo healdi. Here we report and summarize the properties, growth characteristics and phylogenetic affiliations of a cellulolytic, dinitrogenfixing isolate from the shipworm Lyrodus pedicellatus and 58 similar isolates from the gills of nine genera and 24 species of teredinid bivalves. A new genus and species, Teredinibacter turnerae gen. nov., sp. nov., is proposed with strain $\mathrm{T}^{2} 902^{\mathrm{T}}\left(=\right.$ ATCC $39867^{\mathrm{T}}=$ DSM $15152^{\mathrm{T}}$ ) as the type strain.

\section{METHODS}

Culture conditions. Cells were cultivated in a basal medium (shipworm basal medium, SBM) (Waterbury et al., 1983), containing the following: filtered seawater $\left(750 \mathrm{ml} \mathrm{l}^{-1}\right)$, distilled water (250 mg $\left.1^{-1}\right), \mathrm{KH}_{2} \mathrm{PO}_{4}\left(15 \cdot 3 \mathrm{mg} \mathrm{l}^{-1}\right), \mathrm{Na}_{2} \mathrm{CO}_{3}$ $\left(10 \mathrm{mg}^{-1}\right), \mathrm{Na}_{2} \mathrm{MoO}_{4} \cdot 2 \mathrm{H}_{2} \mathrm{O}\left(2 \cdot 5 \mathrm{mg} \mathrm{l}^{-1}\right)$ disodium EDTA $\left(0.5 \mathrm{mg} \mathrm{l}^{-1}\right)$, ferric ammonium citrate (brown crystals) ( $\left.3 \mathrm{mg} \mathrm{l}^{-1}\right)$, HEPES buffer ( $\mathrm{pH} \mathrm{8.0)}\left(5 \cdot 2 \mathrm{~g}^{-1}\right)$ and A5 trace metals (Rippka et al., 1979) $\left(1 \cdot 0 \mathrm{ml} \mathrm{l}^{-1}\right)$. Appropriate carbon sources were added with or without $(5 \mathrm{mM})$ ammonium chloride as a source of combined nitrogen. Cells were incubated at temperatures ranging from 15 to $40{ }^{\circ} \mathrm{C}$. To obtain individual colonies, cells were plated on $1 \%$ agar, SBM plates supplemented with powdered cellulose $(0.2 \%$ w/v) (Sigmacell 100) with or without combined nitrogen. Axenic stock cultures were maintained in SBM agar $(0 \cdot 2 \%)$ and Sigmacell $100(0 \cdot 2 \%)$ without combined nitrogen at room temperature. Maintenance cultures were transferred to fresh medium at 30-day intervals. Stock cultures grown in SBM were amended with $5 \%$ DMSO and cryopreserved in liquid nitrogen. Liquid cultures, used for nucleic acid extractions, contained SBM supplemented with Sigmacell $100(0 \cdot 2 \%)$ and ammonium chloride $(5 \mathrm{mM})$ and were incubated with gentle shaking at $35^{\circ} \mathrm{C}$.

Isolation. Isolates (Table 1) were obtained from gill tissue of freshly collected bivalve specimens by serial dilution as previously described (Waterbury et al., 1983). Gills were removed, washed and homogenized in sterile seawater. Homogenates were used to inoculate $10 \mathrm{ml}$ serial dilutions $\left(10^{1}-10^{10}\right)$ in SBM supplemented with $0 \cdot 2 \%$ agar and powdered cellulose $(0.2 \% \mathrm{w} / \mathrm{v}$, Sigmacell 100) without addition of combined nitrogen. After incubation for 5-10 days at room temperature, cell growth appeared as a lens about $1 \mathrm{~cm}$ below the agar surface. Cells were removed from the greatest dilutions in which growth was observed $\left(10^{7}-\right.$ $10^{8}$ ) and streaked on $1 \%$ agar SBM plates supplemented

Table 1. Strain histories of $T$. turnerae isolates

A complete list of shipworm isolates can be found as supplementary data in IJSEM Online (http://ijs.sgmjournals.org).

\begin{tabular}{|c|c|c|c|}
\hline $\begin{array}{l}\text { Bacterial } \\
\text { strain no.* }\end{array}$ & Host species $\dagger$ & $\begin{array}{c}\text { MCZ } \\
\text { voucher no. }+\end{array}$ & Host source \\
\hline $\mathrm{T} 7902^{\mathrm{T}}$ & $\begin{array}{l}\text { Lyrodus pedicellatus } \\
\text { (Quatrafages) }\end{array}$ & 297526 & $\begin{array}{l}\text { Laboratory Culture, WHOI-ESL. } \\
\text { Original specimens from Long } \\
\text { Beach, CA, USA }\end{array}$ \\
\hline T7901 & Bankia gouldi (Bartsch) & 297551 & $\begin{array}{l}\text { Laboratory Culture, WHOI-ESL. } \\
\text { Original specimens from Duke } \\
\text { University Marine Lab, Beaufort, } \\
\text { NC, USA }\end{array}$ \\
\hline T8402 & Teredora malleolus (Turton) & 297577 & $\begin{array}{l}\text { Floating wood } 190 \mathrm{mi} \text { S.E. of Woods } \\
\text { Hole, MA }\left(38^{\circ} 18 \cdot 4^{\prime} \mathrm{N}, 69^{\circ} 35 \cdot 6^{\prime} \mathrm{W}\right) \text {. } \\
\text { From the West Indies via the Gulf } \\
\text { Stream }\end{array}$ \\
\hline T8602 & Dicyathifer manni (Wright) & 297578 & $\begin{array}{l}\text { Ferguson Point, near Australian } \\
\text { Institute of Marine Science Lab, S. } \\
\text { of Townsville, Qld, Australia }\end{array}$ \\
\hline
\end{tabular}

* Nomenclature - example of strain no. T7902: T, designates an isolate from the bivalve family Teredinidae; 79, the year of isolation (e.g. 1979); 02, the second isolate of that year.

$\dagger$ Host specimens were collected, identified and dissected by Dr Ruth Turner and C. B. Calloway, Museum of Comparative Zoology, Harvard University, Cambridge, MA, USA.

$\$$ Voucher specimens are held in the Mollusc Department of the Museum of Comparative Zoology, Harvard University, Cambridge, MA, USA. They consist of the shells, pallets and remaining soft tissue of the shipworms from which shipworm strains were isolated. 
with Sigmacell $100(0 \cdot 2 \%)$. Individual colonies could be observed on the agar surface after 5 days incubation at room temperature. Colonies were excised with a sterile loop and were used to inoculate fresh liquid medium supplemented with Sigmacell $100(0 \cdot 2 \%)$. After 5 days at room temperature, these liquid cultures were used to inoculate new serial dilutions. Rounds of serial dilution, plating and reinoculation of liquid medium were repeated until axenic isolates were obtained. Host taxa were identified and dissected by Dr Ruth D. Turner or Dr C. B. Calloway and voucher specimens (shells and pallets) are on deposit at the Harvard Museum of Comparative Zoology, Malacology Department, Harvard University, Cambridge, MA, USA (see Table 1). Isolates were named as follows: the letter $\mathrm{T}$ indicates isolates from bivalves of the family Teredinidae, the following two digits indicate the year of isolation and the remaining digits chronologically differentiate strains isolated in a given year.

Phenotypic characterization. Fourteen isolates from stock cultures maintained as described above were streaked on $1 \%$ agar SBM plates supplemented with Sigmacell 100. A single colony was picked from each isolate and restreaked on the same medium, then single colonies from this plate were used to inoculate $25 \mathrm{ml} \mathrm{SBM}$ liquid medium supplemented with $\mathrm{NH}_{4} \mathrm{Cl}(0.025 \%)$ with a strip of Whatman no. 1 filter paper $(1 \times 2 \mathrm{~cm})$ added as a carbon source. Cells grown to mid-exponential phase were then used to inoculate media in glass culture tubes $(15 \times 100 \mathrm{~mm})$. Each tube contained SBM $(10 \mathrm{ml})$ supplemented with $0 \cdot 2 \%$ agar, $\mathrm{NH}_{4} \mathrm{Cl}(0$. $025 \%$ ), 20 mM HEPES (pH 8.0) buffer (except in the tubes containing cellobiose in which $50 \mathrm{mM}$ HEPES was used), $1.0 \%$ phenol red as a $\mathrm{pH}$ indicator, and a selected carbon source. Two additional consecutive transfers were performed in the same medium to confirm growth. Cells were observed using a Zeiss compound microscope $(1000 \times$ magnification). Each isolate was also inoculated into the same medium lacking an added carbon source. After the third transfer on the indicated carbon source each isolate was regrown on $1 \%$ agar SBM plates supplemented with Sigmacell 100 to confirm its identity.

Salt requirements and temperature and $\mathrm{pH}$ range and optima for six isolates (T7901, T7902 ${ }^{\mathrm{T}}$, T7903, T8201, T8202 and T8203) were determined as in (Greene \& Freer, 1986) and (Waterbury et al., 1983).

Catalase activity was assayed with $0.3 \%$ hydrogen peroxide using cells grown in SBM medium in $0.2 \%$ agar stab cultures supplemented with Sigmacell 100 and inoculated from a single colony. Oxidase activity was tested using the Dry Slide Oxidase test kit (Difco). Growth under anaerobic conditions was tested on SBM cellulose in a GasPak system (BBL). Dinitrogenase activity was determined using the acetylene reduction assay on cultures grown in tubes and then capped with rubber stoppers during the assay (Hardy \& Holsten, 1977).

Morphological examination. The type of flagellation was determined by electron microscopy using cells negatively stained with $0.5 \%$ aqueous uranyl acetate. A Philips 300 transmission electron microscope was used to examine samples. Motility, characteristics of cell division, Gram type and staining characteristics were observed by light microscopy using phase-contrast illumination with a Zeiss Standard microscope. Cells for microscopy were grown in SBM supplemented with Sigmacell $100(0 \cdot 2 \%)$ and ammonium chloride $(5 \mathrm{mM})$ and were incubated with gentle shaking at $35^{\circ} \mathrm{C}$. Cells were harvested during exponential- phase growth. Staining to determine Gram type and presence or absence of PHB $(0.3 \%$ Sudan black B) or polyphosphate $(0.3 \%$ methylene blue) was performed as described by Gerhardt (1981).

DNA isolation. Residual cellulose powder was removed from $20 \mathrm{ml}$ of exponential-phase liquid culture by centrifugation $(1000 \mathrm{~g}, 2 \mathrm{~min})$. Cells were then pelleted from the supernatant by centrifugation $(16000 \mathrm{~g}, 5 \mathrm{~min})$. Cells were washed by resuspension in sterile seawater $(100 \mu \mathrm{l})$, pelleted again as above, and resuspended in a final volume of $300 \mu \mathrm{l}$ STET $(0.1 \mathrm{M} \mathrm{NaCl} ; 10 \mathrm{mM}$ Tris/HCl, pH 8.0; $1 \mathrm{mM}$ EDTA, pH $8.0 ; 5 \%$ Triton X-100) containing lysozyme (Sigma) at $10 \mathrm{mg} \mathrm{ml}^{-1}$. Cells were incubated at $37^{\circ} \mathrm{C}$ for $1 \mathrm{~h}$, then Proteinase K (Sigma) was added to a final concentration of $50 \mu \mathrm{g} / \mathrm{ml}$ and incubation was continued overnight at $37^{\circ} \mathrm{C}$. After incubation, $200 \mu \mathrm{l}$ guanidinium (iso)thiocyanate (GSCN) lysis medium [5.0 M guanidinium (iso)thiocyanate, $50 \mathrm{mM}$ Tris/ $\mathrm{HCl}, \mathrm{pH} 7 \cdot 5 ; 50 \mathrm{mM}$ sodium acetate, $\mathrm{pH} 7 \cdot 0$; $25 \mathrm{mM}$ EDTA, pH 8.0] was added to the Proteinase K lysate and gently mixed in a Dounce homogenizer. To the homogenate $60 \mu \mathrm{l}$ sodium lauryl sarcosinate $(10 \% \mathrm{w} / \mathrm{v})$ was added and cellular debris was removed by centrifugation $(2 \times 5 \mathrm{~min}$ at $16000 \mathrm{~g})$. Nucleic acids were precipitated by addition of one volume of cold absolute ethanol to the supernatant followed by centrifugation $(2 \mathrm{~min}$ at $16000 \mathrm{~g}$ ). The resulting pellet was dissolved by trituration in $100 \mu \mathrm{l}$ $6 \mathrm{M}$ guanidine. $\mathrm{HCl}$ and undissolved material was removed by centrifugation $(2 \times 5 \mathrm{~min}$ at $16000 \mathrm{~g})$. Nucleic acids were precipitated by centrifugation $(2 \mathrm{~min}$ at $16000 \mathrm{~g}$ ) after addition of $2 \cdot 5$ volumes of cold ethanol and $1 / 10$ volume of $3 \mathrm{M}$ sodium acetate. The pellet was washed with $70 \%$ ethanol $(100 \mu \mathrm{l})$, lightly dried under vacuum and dissolved in $50 \mu \mathrm{TE}$ buffer (1 mM EDTA; $10 \mathrm{mM}$ Tris/HCl, $\mathrm{pH} 7 \cdot 4)$. Residual protein was removed by organic extraction (Sambrook et al., 1989) with phenol:chloroform : isoamyl alcohol $(25: 24: 1)$ and chloroform: isoamyl alcohol $(24: 1)$ followed by ethanol precipitation and dissolution in TE buffer as above.

DNA base composition. DNA base composition was determined by thermal denaturation as in (Herdman et al., 1979).

PCR amplification. Bacterial $16 \mathrm{~S}$ rDNAs were amplified by PCR (Saiki et al., 1987) from genomic nucleic acid extracted from shipworm isolates using bacterial-domain-specific primers 27f (AGAGTTTGATCATGGCTCAG) and 1492r (GGTTACCTTGTTACGACTT) (Lane, 1991). Reactions were carried out in $50 \mu \mathrm{l}$ volumes containing $4.4 \mu \mathrm{l}$ AmpliTaq (Perkin Elmer) $10 \times$ PCR buffer, $1.8 \mathrm{mM} \mathrm{MgCl}_{2}$, $25 \mathrm{mM}$ each dATP, dCTP, dGTP and dTTP; $100 \mathrm{nM}$ each primer, 1.25 U AmpliTaq DNA polymerase (Perkin Elmer) and $0 \cdot 2 \mathrm{ng}$ template nucleic acid $\mu 1^{-1}$. PCR reactions used the following parameters: presoak: $94{ }^{\circ} \mathrm{C}, 1 \mathrm{~min} ; 35$ cycles of $1 \mathrm{~min}$ each at 94,60 and $72^{\circ} \mathrm{C}$; post-soak: $72^{\circ} \mathrm{C}, 7 \mathrm{~min}$. Amplification products $(\sim 1.5 \mathrm{~kb})$ were visualized by gel electrophoresis ( $0.8 \%$ agarose, $0.5 \times$ TBE, (Sambrook et al., 1989). Reaction products were purified and concentrated by ultrafiltration (Microcon YM100 spin microconcentrator; Amicon) prior to sequencing.

16S rRNA gene sequencing. Sequencing reactions were performed using the ABI Prism Dye Terminator Cycle Sequencing Ready Reaction kit (Applied Biosystems) using AmpliTaq FS DNA Polymerase, on an ABI 373A DNA sequencer. Nearly complete double-stranded sequence of the 16S rRNA gene (1453 bp) was determined from PCR products using primers : 27f, 1492r, 357f (CTCCTACGGA- 
GGCAGCAG), 704f (GGTGAAATGCGTAGA), 907r (CCGTCAATTCMTTTRAGTTT), 1101r (AGGGTTGCGCTCGTT) and 690r (TCTACGCATTTCACC) (Lane, 1991).

Phylogenetic analyses. Alignments were designed to maximize agreement with the proposed secondary structure for the Escherichia coli (Gutell, 1994). Agreement with this model was verified in new sequences by the occurrence of compensatory substitutions that preserve secondary structure in conserved internal helices. Gaps were inserted to compensate for length variation in identified loops and helices or to accommodate missing data. No additional gaps were added to increase primary sequence similarity among taxa. Sites within regions of uncertain alignment were identified and eliminated from further analyses. Alignments were edited using SeqLab (GCG version 10.1). The sequence of the T7902 $16 \mathrm{~S}$ rDNA is on deposit in the GenBank sequence database (accession no. AY028398).

Fifty reference taxa were selected to represent the diversity within the gamma subclass of proteobacteria with emphasis on lineages with highest $16 \mathrm{~S}$ rDNA sequence identity to the shipworm isolates, as identified through BLAST searches of GenBank and searches of the Ribosomal Database Project (RDP) database using Sequence Match version 2.7 (Maidak et al., 2001). Additional sequences of subjective interest (selected bivalve gill endosymbionts and taxa with known cellulolytic capabilities) were also considered.

Phylogeny reconstruction. Phylogenetic analyses were performed using algorithms contained in PAUP* (version 4.0b8) (Swofford, 1997). Maximum-parsimony, maximum-likelihood and evolutionary distance methods were used to infer tree topology. Maximum-likelihood trees were inferred using the HKY 85 substitution model (Hasegawa et al., 1985) with ti:tv $=2$, empirical base frequencies and equal rates for all sites. Maximum-parsimony analyses were performed with character states optimized by accelerated transformation (ACCTRAN). Evolutionary distance analyses used Kimura two-parameter distances the minimum evolution as the objective criterion and equal rates for all sites. In all analyses branch swapping was by tree-bisection-reconnection $(\mathrm{TBR})$ with characters weighted equally (weight $=1$ ) and gaps were treated as missing data. Bootstrap analyses were performed using the full heuristic search option with 1000 replicates for maximum-parsimony and evolutionary distance analyses. Bootstrap analyses under maximumlikelihood were limited to 100 replicates on a reduced taxa set (33 taxa) to accommodate the greater computational demands of this technique. Uncorrected pair-wise distance estimates for comparative purposes were estimated using Sequence Match version 2.7 and sequences selected from the Ribosomal Database Project (Maidak et al., 2001).

\section{RESULTS}

\section{Phenotypic characteristics of shipworm isolates}

Fifty-eight bacterial isolates similar to each other in morphology and growth characteristics were obtained from gill tissues dissected from 24 species of teredinid bivalves collected in various locations [see Table 1, plus additional data in supplementary data in IJSEM Online (http://ijs.sgmjournals.org)]. All isolates were highly motile, slightly curved, rod-shaped cells of uniform dimensions $(0.4-0.6 \times 3-6 \mu \mathrm{m})$ bearing a single polar flagellum and granular inclusions near each cell apex when observed during exponentialphase growth in SBM medium with cellulose as a sole carbon source (Fig. 1). The granular inclusions are phase- and electron-dense and are consistent with polyphosphate in staining characteristics (staining with methylene blue but not Sudan black) and in appearance in transmission electrom micrographs. All fix dinitrogen and display characteristics of microaerophilic growth when inoculated in soft agar stab cultures. All isolates display a distinctive colony morphology when grown on SBM cellulose with growth occurring as a diffuse inverted dome beneath the surface of the agar. Young colonies are translucent and difficult to discern while older colonies may produce a yellow-brown pigment and are surrounded by a broad halo of clearing due to cellulose hydrolysis. Shallow depressions may form on the surface of older colonies. These are most likely due to the removal of solid cellulose from the medium. The depressions do not deepen after clearing of the cellulose and there is no evidence that agar is hydrolysed. No growth is observed on agar in the absence of a suitable carbon source. Cell morphology varied for individual isolates on different carbon sources, ranging from motile rods to non-motile rods, helices, spheres, or pleomorphic forms. DNA $\mathrm{G}+\mathrm{C}$ content for tested isolates ranged was $49-51 \mathrm{~mol} \%$.

Growth of all isolates is supported by cellulose (Whatman no. 1 filter paper or Sigmacell 100 cellulose powder) with or without an added source of combined nitrogen. Fourteen isolates tested (T7901-T7903, T8201-T8203, T8304, T8402, T8505, T8506, T8508, T8509, T8601 and T8602) also showed growth on carboxymethylcellulose $(0.5 \%)$, cellobiose $(0.5 \%)$, fructose $(0.5 \%)$, salicin $(0.5 \%)$, glutamate $(0.1 \%)$, succinate $(0.1 \%)$, pyruvate $(0.1 \%)$, pectin $(0.5 \%)$ and xylan $(0.5 \%)$. Most tested isolates also exhibit growth on sucrose $(0.5 \%$; except T8304), xylose $(0.5 \%$; except T8509), yeast extract $(0 \cdot 1 \%$; except T7901), acetate (0.1\%; except T7901, T8509 and T8602) and glucose (0.5\%; except T8202, T8505, T8506, T8509 and T8601). A yellow pigment was produced by some isolates during growth on Sigmacell 100, Whatman no. 1 filter paper, cellobiose and salicin, and acid production was observed by all isolates with growth on sucrose, fructose, xylose, glucose, pectin, salicin, cellobiose, Sigmacell 100 and Whatman no. 1 filter paper. No growth was observed on dextrin, trehalose, melezitose, or in controls to which no carbon source was added.

The $\mathrm{pH}$, temperature and salinity optima for growth have been determined for six isolates $\left(\mathrm{T} 7901, \mathrm{~T} 7902^{\mathrm{T}}\right.$, T7903, T8201, T8202 and T8203) and are approximately $8 \cdot 5,30-35^{\circ} \mathrm{C}$ and $0.3 \mathrm{M} \mathrm{NaCl}$ respectively. No growth occurs above $39^{\circ} \mathrm{C}$. Specific growth rates measured at $35^{\circ} \mathrm{C}$ in the presence and absence of combined nitrogen were 0.12 and 0.05 per hour, respectively. The isolates are marine, i.e. in addition to $\mathrm{NaCl}$ they require elevated concentrations of $\mathrm{Ca}^{2+}$ and $\mathrm{Mg}^{2+}$ that reflect the chemistry of seawater (Greene \& 

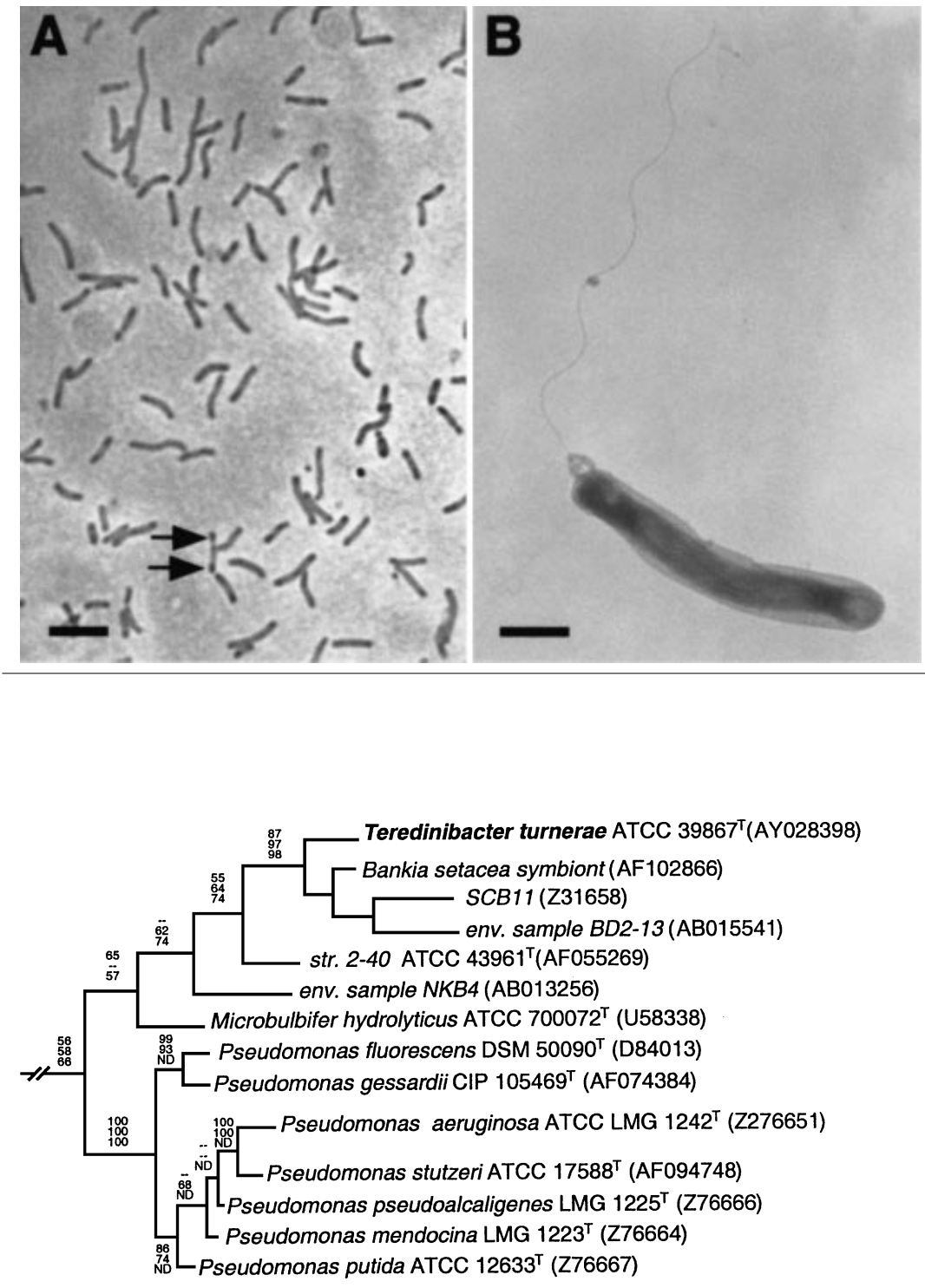

-10 changes
Fig. 1. Teredinibacter turnerae strain $\mathrm{T}^{\mathrm{T}} \mathrm{T}^{\top}{ }^{\top}$. (A) Phase-contrast light micrograph. Arrows indicate phase-dense apical granular inclusions. (B) Negatively stained transmission electron micrograph. Note single polar flagellum. Cells were grown in SBM supplemented with Sigmacell $100 \quad(0.2 \%)$ and ammonium chloride $(5 \mathrm{mM})$ and were incubated with gentle shaking at $35^{\circ} \mathrm{C}$. Cells were harvested during exponential phase of growth. Scale bars: A, $5 \mu \mathrm{m} ; \mathrm{B}, 1 \mu \mathrm{m}$.

Fig. 2. Phylogenetic tree for Teredinibacter turnerae $\mathrm{T7902}^{\mathrm{T}}$ and representative $\gamma$ Proteobacteria extracted from a single best tree of 2628 steps inferred by maximumparsimony using $16 \mathrm{~S}$ rRNA sequence data (1158 unambiguous aligned sites for 51 taxa, PAup* version 4.0, see Methods). The complete tree can be viewed in IJSEM Online (http://ijs.sgmjournals.org). Best trees inferred by maximum-likelihood and evolutionary distance methods (not shown) were topologically identical with the maximumparsimony tree with respect to all nodes receiving significant $(>70 \%)$ bootstrap support. Bootstrap proportions are presented at each node: distance (top), parsimony (middle) and likelihood (bottom). Bootstrap proportions for distance and parsimony analyses are expressed as percentage of 1000 replicates. Bootstrap proportions for maximum-likelihood were computed using 100 replicates and 33 taxa. Dashes $=$ bootstrap value $<50 \%$.
Freer, 1986; Waterbury et al., 1983). Strain T7902 ${ }^{\mathrm{T}}$ exhibits catalase and oxidase activity.

\section{Phylogenetic analyses}

Nearly complete sequence (1453 bp) was determined for the 16S rRNA gene of strain T7902 ${ }^{\mathrm{T}}$. This sequence was indistinguishable from partial sequences (891 positions examined) determined previously for isolates T7902 ${ }^{\mathrm{T}}$, T8402, T8602, T7901 (GenBank accession nos M64338-40) by reverse transcriptase sequencing of purified rRNAs (Distel et al., 1991). The T7902 sequence was aligned (accounting for rRNA structure) with 50 published bacterial $16 \mathrm{~S}$ sequences (taxon names, isolate and sequence accession numbers are listed in Fig. 2, and on-line supplementary material). A mask was employed to eliminate sites containing missing or ambiguous data and sites within regions of uncertain alignment, leaving a final character set of
1158 nucleotide positions, 376 of which are parsimony informative. Phylogenetic analyses were conducted using maximum-likelihood, maximum-parsimony and evolutionary distance methods.

A heuristic search by maximum-parsimony retained a single best tree of 2628 steps [consistency index $(\mathrm{CI})=$ $0 \cdot 3006$, homoplasy index $(\mathrm{HI})=0 \cdot 6994$, retention in$\operatorname{dex}(\mathrm{RI})=0.5782$, and rescaled consistency index $(\mathrm{RC})=0 \cdot 1738]$ (Fig. 2). Evolutionary distance analysis retained a single best tree with minimum evolution score of $2 \cdot 10605$. Maximum-likelihood analysis retained a single best tree with $-\ln$ likelihood $=$ 15893.05033 . Best trees inferred by all methods are topologically identical with respect to nodes supported by significant bootstrap proportions.

Trees inferred by all methods include shipworm strain T7902 $2^{\mathrm{T}}$ within a clade containing an uncultivated symbiont from the shipworm Bankia setacea (Gen- 
Bank no. AF102866) (Sipe et al., 2000), an undescribed marine heterotrophic isolate from the Southern California coast (SCB11, GenBank no. Z31658) (Rehnstam et al., 1993), and an uncultivated bacterium from deep-sea sediments in Sugura Bay, Japan (1521 m; 34 55', 138 39') (BD2-13, GenBank no. AB015541) (Li et al., 1999). This clade (hereafter referred to as the Teredinibacter clade) receives significant bootstrap support (87-98\%) by all inference methods. Three additional taxa are placed at the base of this clade in maximum-likelihood and maximumparsimony analyses. These taxa include strain 2-40 (GenBank no. AF055269) (Gonzalez \& Weiner, 2000) isolated from salt marsh cord grass Spartina alterniflora in the Chesapeake Bay, VA; an uncultivated bacterium (NKB4, GenBank no. AB013256) from deep-sea sediments near a cold-seep bivalve community in the Nankai Trough, Japan (3843 m; 33 $39^{\prime}$, $\left.137^{\circ} 56^{\prime}\right)$ (Li et al., 1999) and Microbulbifer hydrolyticus str. IRE-31 (ATCC 700072, GenBank no. U58338) (Gonzalez et al., 1997) a marine heterotroph isolated from pulp mill effluents inoculated with water from a sea-grass bed (Sapelo Island, GA). The latter two form a sister group to the group that contains the Teredinibacter clade $+2-40$ in evolutionary distance analyses. The groups that include the Teredinibacter clade $+2-40$ and the Teredinibacter clade $+2-40+$ NKB4 + IRE-31 receive no significant bootstrap support in maximum-parsimony and evolutionary distance analyses and only weak support in the maximumlikelihood analysis. Uncorrected pair-wise identity values estimated for $16 \mathrm{~S}$ rDNAs of strain $\mathrm{T} 7902^{\mathrm{T}}$ and its closest described relatives, IRE-31 and 2-40, are approximately 89 and $91 \%$ respectively.

Additional analyses using less complete sequences available in GenBank (data not shown) suggest that four additional sequences may be associated with the Teredinibacter clade. This group does not receive significant bootstrap support, however, resolution may be limited due in part to the small number of nucleotide positions determined for these taxa. These sequences include uncultivated symbionts ('Candidatus Endobugula sertula' BnSP (GenBank no. AF06606), BnPV (AF06607) and BnTP (AF06608)) from larvae of a bryozoan Bugula neretina, and an uncultivated bacterium (HstpL85_st, GenBank no. AF159682) detected on the surface of sea grass Halophila stipulacea.

\section{DISCUSSION}

All 58 strains isolated from gill tissue of shipworms were very similar to each other with respect to morphology, physiological characteristics and substrate utilization. Growth rates, temperature ranges and optima for growth, $\mathrm{pH}$ and salt requirements and $\mathrm{G}+\mathrm{C}$ content were similar for all strains tested (T7901, T7902 ${ }^{\mathrm{T}}$, T7903, T8201, T8202 and T8203) (Greene, 1989; Waterbury et al., 1983) and 16S rRNA sequences were identical over 891 positions examined for four strains tested (T7901, T7902 ${ }^{\mathrm{T}}, \mathrm{T} 8402$ and T8602)
(Distel et al., 1991). All strains were isolated from shipworm gill tissue at dilutions of at least $10^{-7}-10^{-8}$ and all grow on cellulose as a sole carbon source and fix dinitrogen under microaerobic conditions.

The shipworm isolates are unique in several respects. First, of the many intracellular endosymbionts of marine invertebrates that have been identified by microscopic and molecular methods in the past quarter century, the shipworm isolates remain the only such bacteria to be grown in pure culture. The endosymbiotic status of the shipworm isolates has been confirmed by culture-based (Waterbury et al., 1983) and molecular methods (Distel et al., 1991).

Second, the shipworm isolates are phylogenetically unique. In the 20 years since their cultivation was first reported, no bacterium, cultivated or uncultivated, has been shown to be closely related to the shipworm isolates by molecular phylogenetic methods. While there are currently no accepted criteria for delimiting prokaryotic taxa based on comparative analyses of gene sequences, comparisons of pair-wise sequence identities of ribosomal rDNAs are frequently reported and may be informative in cases where sequence differences are extreme. For example, it has been shown that bacteria that share less than $97.5 \%$ sequence identity typically do not show greater than $60-70 \%$ DNA similarity by a variety of reassociation methods and so are unlikely to be related at the species level (Stackebrandt \& Goebel, 1994). Searches of GenBank and RDP databases using BLAST and Sequence Match version 2.7, followed by alignment and estimation of pair-wise identity using Similarity Matrix 1.1 (RDP) demonstrate that the closest cultivated and characterized relative of strain $\mathrm{T} 7902^{\mathrm{T}}$ shares only about $91 \%$ identity in its $16 \mathrm{~S}$ rDNA sequence. For comparison, all 29 species included in the genus Pseudomonas sensu stricto (Anzai et al., 1997, 2000) share greater than $93.3 \%$ identity and species of Escherichia, Erwinia, Enterobacter, Citrobacter, Klebsiella, Proteus, Salmonella, Serratia, Yersinia, Xenorhabdus and many other genera within the family Enterobacteriaceae share greater than $91 \%$ identity by the same estimation method. Thus, $\mathrm{T} 7902^{\mathrm{T}}$ differs from its nearest described relatives by values substantially exceeding those that separate many welldefined genera.

Third, the shipworm isolates are physiologically unique. Their ability to grow with cellulose as a sole carbon source and to fix nitrogen is a rare combination. Similar capabilities have been reported in several strictly anaerobic Gram-positive bacteria, e.g. Clostridium hungatei (Monserrate et al., 2001). Functional endoglucanase genes have also been identified in dinitrogen-fixing, rhizosphere-associated bacteria from the $\alpha$-Proteobacteria, e.g. Azospirillum irakense (Faure et al., 2001) and Azorhizobium caulinodans (Geelen et al., 1995), and beta proteobacteria, e.g. Azoarcus sp. (Reinhold-Hurek et al., 1993). However, these bacteria do not grow with cellulose as a sole carbon source and probably use their cellulolytic 
capabilities as a means to penetrate plant tissues. To our knowledge, the shipworm isolates are the only Gram-negative bacteria described to date that fix dinitrogen and grow with cellulose as a sole carbon source, and the only bacterium that combines these capabilities to grow under (micro)aerobic conditions.

Fourth, the shipworm isolates are unusual in terms of their distinctive habitat. This bacterium has only been cultivated from gill tissues of wood-boring marine bivalves of the family Teredinidae (shipworms) where it exists as an endosymbiont. Attempts to cultivate this bacterium from other tissues of shipworms, from wood surfaces and from seawater surrounding or within shipworm burrows have been unsuccessful (Waterbury et al., 1983). This contrasts with cultivable symbionts of other marine invertebrates, e.g. the Vibrio fischeri and $V$. logei strains that exist extracellularly in the lumen of the light organ crypts of squid but that also can be cultivated easily from water in which the hosts have been maintained (Nishiguchi, 2000). The ability of $\mathrm{T} 7902^{\mathrm{T}}$ to exist as an endosymbiont in a specific animal group is in itself a highly unusual phenotype.

Of the taxa identified here as potential affiliates of the shipworm isolate $\mathrm{T} 7902^{\mathrm{T}}$, only two (marine bacterium strain 2-40; ATCC $43961^{\mathrm{T}}$ and Microbulbifer hydrolyticus str. IRE-31 ATCC $700072^{\mathrm{T}}$ ) have been cultivated and characterized physiologically. Strain 2-40 is a strictly aerobic marine heterotroph capable of hydrolysing a broad range of complex polysaccharides, including agar, carboxymethylcellulose (but not cellulose), chitin, laminarin and xylans (Gonzalez \& Weiner, 2000). A previous report suggested that strain 2-40 and the shipworm isolates should be placed into the genus Microbulbifer based on 16S rDNA sequence analysis (Gonzalez \& Weiner, 2000). The type strain Microbulbifer hydrolyticus str. IRE-31 (ATCC $700072^{\mathrm{T}}$ ) is a marine heterotroph isolated from pulp mill effluents inoculated with water from a seagrass bed (Sapelo Island, GA) (Gonzalez et al., 1997). Results presented here, based on a larger and more representative taxa set and on a significantly larger number of nucleotide characters show little or no support for this generic assignment. Only one of the three phylogenetic inference methods (maximum-likelihood) employed in this study provided some, albeit weak, bootstrap support $(<75 \%)$ for inclusion of these taxa within a single clade. However, due to the greater computational demands of the technique, the maximum-likelihood bootstrap analysis included a smaller number of taxa (33 vs 51 for parsimony and distance analyses) and so this result may reflect poor taxa sampling rather than a significant relationship that was undetected by the other methods. Notably, bootstrap proportions in the majority of analyses performed here and in analysis published previously (Gonzalez \& Weiner, 2000), fall short of the value $(70 \%)$ often considered a minimum threshold for phylogenetic support (Hillis \& Bull, 1993). Furthermore, $M$. hydrolyticus str. IRE-31 shares only about $89 \cdot 2 \%$ identity with $T$. turnerae, a distance that exceeds those observed among many bacteria distinguished at the ordinal level. For example, Escherichia coli (ATCC $11775^{\mathrm{T}}$, GenBank X80725) shares 89.7 and $89.5 \%$ identity with Aeromonas hydrophila (ATCC $7966^{\mathrm{T}}$; X60404) and Vibrio fisheri (NCIMB $1281^{\mathrm{T}}$, GenBank X74702), respectively. Moreover, strain 2-40 and IRE31 share only about $91.1 \%$ 16S rDNA sequence identity. Given the large evolutionary distances that separate strain 2-40 from IRE-31 and T. turnerae, and the weak phylogenetic support for affiliation observed in this study, a common generic assignment for these taxa is unwarranted.

In addition to weak phylogenetic support, a considerable number of differences also exist between the shipworm isolates and the aforementioned taxa with respect to cell morphology, metabolism and habitat (Table 2). For example, under the conditions employed in this investigation surface membrane blebs characteristic of strain IRE-31 and strain 2-40 were not observed in the shipworm isolates. Also, the shipworm isolates are able to fix dinitrogen under microaerobic conditions, contain characteristic granular inclusions near the tips of the cells, form characteristic subsurface colonies on SBM cellulose plates and fail to grow on Difco marine agar or LB agar plates. These characteristics differ from those reported for strain IRE-31 and strain 2-40. Finally, mol $\% \mathrm{G}+\mathrm{C}$ for the shipworm isolates ranges from 49 to 51 (six isolates tested) vs 46.7 for strain $2-40$ and 57.6 for strain IRE-31. Therefore, on the basis of its unique combination of physiological properties, phylogenetic position and specific symbiotic association with wood-boring bivalves of the family Teredinidae, we propose a new genus and species, Teredinibacter turnerae gen. nov., sp. nov., with $\mathrm{T} 7902^{\mathrm{T}}$ as the type strain. Three additional strains (Table 1), which are indistinguishable from strain $\mathrm{T} 7902^{\mathrm{T}}$ with respect to $16 \mathrm{~S}$ rRNA sequence, are also included within the proposed species. Data available to date suggest that the remaining strains, described herein and in supplementary data in IJSEM Online (http://ijs.sgmjournals. org), will fall within the new species upon more complete characterization.

\section{Description of Teredinibacter gen. nov.}

Teredinibacter [Ter.e.din.i.bac'ter. N.L. fem. pl. n. Teredinidae a family of wood-boring bivalve molluscs (shipworms); N.L. masc. n. bacter, equivalent of bacterium, a staff or rod; N.L. masc. n. Teredinibacter a rod isolated from members of the family Teredinidae].

Cells are rigid, Gram-negative rods of $0 \cdot 4-0.6 \mu \mathrm{m}$ in width and 3-6 $\mu \mathrm{m}$ in length during exponential-phase growth on SBM medium with cellulose as a carbon source. Division is by binary fission in a single plane. Motile by means of single polar flagellum. In stationary-phase cultures, cells often become pleomorphic, appearing spiraled or as very long rods. Occur in nature as long rods associated with the gill system of 
Table 2. Characteristics of Teredinibacter turnerae and related bacteria

\begin{tabular}{|c|c|c|c|}
\hline Trait & Teredinibacter turnerae & Strain 2-40 & $\begin{array}{c}\text { Microbulbifer } \\
\text { hydrolyticus }\end{array}$ \\
\hline Cell shape & Rods & Pleomorphic rods & Rods \\
\hline Cell length & $3-6 \mu \mathrm{m}$ & $1-20 \mu \mathrm{m}$ & $1 \cdot 1-1 \cdot 7 \mu \mathrm{m}$ \\
\hline Cell arrangement & Single & Single, chains & Single, chains \\
\hline Flagellum & Single, polar & Single, polar & None \\
\hline Surface nodules & - & + & + \\
\hline Salt requirement for growth & Marine & Marine & Marine \\
\hline Vitamin requirement & - & $\begin{array}{l}\text { B cofactors } \\
\text { stimulatory }\end{array}$ & - \\
\hline $\begin{array}{l}\text { Growth on monosaccharides } \\
\text { Hydrolysis of: }\end{array}$ & + & + & Limited \\
\hline Cellulose & + & - & + \\
\hline Agar & - & + & - \\
\hline Nitrogen fixation & + & $?$ & - \\
\hline Habitat & $\begin{array}{l}\text { Endosymbionts of } \\
\text { teredinid bivalves }\end{array}$ & $\begin{array}{l}\text { Free-living, } \\
\text { salt marsh }\end{array}$ & $\begin{array}{l}\text { Free-living, } \\
\text { salt marsh }\end{array}$ \\
\hline $\mathrm{Mol} \% \mathrm{G}+\mathrm{C}$ & $49-51$ & $46 \cdot 7$ & $57 \cdot 6$ \\
\hline
\end{tabular}

teredinid molluscs. Aerobic chemoheterotrophs that grow in a simple mineral medium containing seawater and a suitable carbon and energy source (e.g. cellulose, simple sugars and organic acids). Require a source of combined nitrogen if vigorously aerated but will fix dinitrogen when grown in the absence of combined nitrogen under microaerobic conditions. Analysis of their 16S rDNA indicates that the genus belongs to a unique clade of the $\gamma$-Proteobacteria. Type species is Teredinibacter turnerae.

\section{Description of Teredinibacter turnerae sp. nov.}

Teredinibacter turnerae (tur'ner.ae. N.L. fem. n. turnerae of Turner, named after Ruth D. Turner, malacologist at the Museum of Comparative Zoology, Harvard University).

In addition to the characteristics of the genus, the species characterization is based on the properties of the type strain (T7902) and three additional strains (T7901, T8402 and T8602 ${ }^{\mathrm{T}}$ ) isolated from phylogenetically divergent species and genera of teredinid molluscs collected in distantly separated locations in the Atlantic and Pacific Oceans. All isolates grew on cellulose with or without an added source of combined nitrogen and also demonstrated growth on carboxymethylcellulose, cellobiose, fructose, salicin, glutamate, succinate, pyruvate, pectin, xylan, sucrose, xylose, yeast extract and glucose. All but T8604 also grew on acetate. Acid was produced by all isolates when grown on sucrose, fructose, xylose, glucose, pectin, salicin, cellobiose and cellulose. The temperature range for growth is approximately $20-30^{\circ} \mathrm{C}$, with optimal growth occurring at $30-35^{\circ} \mathrm{C}$. No growth is observed at 15 or $40{ }^{\circ} \mathrm{C}$. The optimum $\mathrm{pH}$ for growth is 8.5 and the $\mathrm{pH}$ range for growth is $6 \cdot 0-10 \cdot 5$. The $\mathrm{NaCl}$ range for growth is $0 \cdot 1-0.6 \mathrm{M}$, and optimal growth occurs at $0.3 \mathrm{M}$. Growth also requires elevated concentrations of $\mathrm{Ca}^{2+}$ and $\mathrm{Mg}^{2+}$ that reflect the chemistry of seawater. Growth factors are not required. T7902 $2^{\mathrm{T}}$ exhibits oxidase and catalase activity. No growth was observed under anaerobic conditions on SBM agar with cellulose as the carbon source. Colonies are translucent with all growth occurring beneath the agar surface. As colonies age a yellowbrown pigment is observed and clearing occurs around the colonies due to cellulose hydrolysis. The $\mathrm{G}+\mathrm{C}$ content of the DNA is $49-51 \mathrm{~mol} \%$. The type strain $\mathrm{T} 7902^{\mathrm{T}}\left(=\right.$ ATCC $\left.39867^{\mathrm{T}}=\mathrm{DSM} 15152^{\mathrm{T}}\right)$ was isolated from Lyrodus pedicellatus originally collected from Long Beach, CA, USA, but kept in culture at Woods Hole Oceanographic Institution for many years.

\section{ACKNOWLEDGEMENTS}

This work was supported by grants from the National Science Foundation no. NSF DEB-9420051 and IBN9982982, the Maine Science and Technology Foundation's Center for Innovation in Biotechnology, and the University of Maine's Faculty Research program. We would like to acknowledge the contributions of Dr C. B. Calloway and Dr Ruth D. Turner (deceased 30 April 2000) who provided and identified many of the specimens used in this investigation and to whom this manuscript is dedicated.

\section{REFERENCES}

Anzai, Y., Kim, H., Park, J. Y., Wakabayashi, H. \& Oyaizu, H. (2000). Phylogenetic affiliation of the pseudomonads based on $16 \mathrm{~S}$ rRNA sequence. Int J Syst Evol Microbiol 50, 1563-1589.

Anzai, Y., Kudo, Y. \& Oyaizu, H. (1997). The phylogeny of the genera Chryseomonas, Flavimonas, and Pseudomonas supports synonymy of these three genera. Int J Syst Bacteriol 47, 249-251.

Distel, D. L., Delong, E. F. \& Waterbury, J. B. (1991). Phylogenetic characterization and in situ localization of the bacterial symbiont of shipworms (Teredinidae: Bivalvia) by using 16S rRNA sequence 
analysis and oligonucleotide probe hybridization. Appl Environ Microbiol 57, 2376-2382.

Distel, D. L. \& Roberts, S. J. (1997). Bacterial endosymbionts in the gills of the deep-sea wood-boring bivalves Xylophaga atlantica and Xylophaga washingtona. Biol Bull 192, 253-261.

Faure, D., Henrissat, B., Ptacek, D., Bekri, M. A. \& Vanderleyden, J. (2001). The celA gene, encoding a glycosyl hydrolase family 3 betaglucosidase in Azospirillum irakense, is required for optimal growth on cellobiosides. Appl Environ Microbiol 67, 2380-2383.

Fisher, C. R. (1990). Chemoautotrophic and methanotrophic symbioses in marine invertebrates. Rev Aquat Sci 2, 399-436.

Geelen, D., van Montagu, M. \& Holsters, M. (1995). Cloning of an Azorhizobium caulinodans endoglucanase gene and analysis of its role in symbiosis. Appl Environ Microbiol 61, 3304-3310.

Gerhardt, P. (1981). Manual of Methods in General Bacteriology. Washington, DC: American Society for Microbiology.

Gonzalez, J. M. \& Weiner, R. M. (2000). Phylogenetic characterization of marine bacterium strain 2-40, a degrader of complex polysaccharides. Int J Syst Evol Microbiol 50, 831-834.

Gonzalez, J. M., Mayer, F., Moran, M. A., Hodson, R. E. \& Whitman, W. B. (1997). Microbulbifer hydrolyticus gen. nov., sp. nov., and Marinobacterium georgiense gen. nov., sp. nov., two marine bacteria from a lignin-rich pulp mill waste enrichment community. Int J Syst Bacteriol 47, 369-376.

Greene, R. V. (1989). A novel, symbiotic bacterium isolated from marine shipworm secretes proteolytic activity. Curr Microbiol 19, 353-356.

Greene, R. V. (1994). Challenges from the sea: marine shipworms and their symbiotic bacterium. SIM News 44, 51-59.

Greene, R. V. \& Freer, S. N. (1986). Growth characteristics of a novel nitrogen-fixing cellulolytic bacterium. Appl Environ Microbiol 52, 982-986.

Greene, R. V., Griffin, H. L. \& Freer, S. N. (1988). Purification and characterization of an extracellular endoglucanase from the marine shipworm bacterium. Arch Biochem Biophys 267, 334-341.

Gutell, R. R. (1994). Collection of small subunit (16S- and 16S-like) ribosomal RNA structures: 1994. Nucleic Acids Res 22, 3502-3507.

Hardy, R. W. F. \& Holsten, R. D. (1977). In A Treatise on Dinitrogen Fixation, section 4, pp. 451. Edited by R. W. F. Hardy \& H. Gibson. New York: Wiley.

Hasegawa, M., lida, Y., Yano, T., Takaiwa, F. \& Iwabuchi, M. (1985). Phylogenetic relationships among eukaryotic kingdoms inferred from ribosomal RNA sequences. $J$ Mol Evol 22, 32-38.

Herdman, M., Janvier, M., Waterbury, J. B., Rippka, R., Stanier, R. \& Mandel, M. (1979). Deoxyribonucleic acid base composition of Cyanobacteria. J Gen Microbiol 111, 63-71.

Hillis, D. M. \& Bull, J. J. (1993). An empirical test of bootstrapping as a method for assessing confidence in phylogenetic analysis. Syst Biol 42, $182-192$.
Imam, S. H., Greene, R. V. \& Griffin, H. L. (1990). Adhesive properties of a symbiotic bacterium from a wood-boring marine shipworm. Appl Environ Micorbiol 56, 1317-1322.

Imam, S. H., Greene, R. V. \& Griffin, H. L. (1993). Binding of extracellular carboxymethylcellulase activity from the marine shipworm bacterium to insoluble cellulosic substrates. Appl Environ Microbiol 59, $1259-1263$

Lane, D. J. (1991). 16S/23S sequencing. In Nucleic Acid Techniques in Bacterial Systematics, pp. 115-175. Edited by E. Stackebrandt \& M. Goodfellow. New York: Wiley.

Li, L., Guezennec, J., Nichols, P., Henry, P., Yanagibayashi, M. \& Kato, C. (1999). Microbial diversity in Nankai Trough sediments at a depth of 3,843 m. J Oceanogr 55, 635-642.

Maidak, B. L., Cole, J. R., Lilburn, T. G. \& 7 other authors (2001). The RDP-II (Ribosomal Database Project). Nucleic Acids Res 29, 173-174.

Monserrate, E., Leschine, S. B. \& Canale-Parola, E. (2001). Clostridium hungatei sp. nov., a mesophilic, $\mathrm{N}_{2}$-fixing cellulolytic bacterium isolated from soil. Int J Syst Evol Microbiol 51, 123-132.

Nishiguchi, M. K. (2000). Temperature affects species distribution in symbiotic populations of Vibrio spp. Appl Environ Microbiol 66, 3550-3555.

Rehnstam, A.-S., Bachman, S., Smith, D. C., Azam, F. \& Hagstrom, A. (1993). Blooms of sequence-specific culturable bacteria in the sea. FEMS Microbiol Ecol 102, 161-166.

Reinhold-Hurek, B., Hurek, T., Claeyssens, M. \& van Montagu, M. (1993). Cloning, expression in Escherichia coli, and characterization of cellulolytic enzymes of Azoarcus sp., a root-invading diazotroph. $J$ Bacteriol 175, 7056-7065.

Rippka, R., Derueles, J., Waterbury, J. B., Herdman, M. \& Stanier, R. Y. (1979). Generic assignments, strain histories and properties of pure cultures of cyanobacteria. J Gen Microbiol 11, 1-61.

Saiki, R., Gelfand, D. H., Stoffel, S., Scharf, S. J., Higuchi, R., Horn, G. T., Mullis, K. B. \& Erlich, H. A. (1987). Primer-directed enzymatic amplification of DNA with a thermostable DNA polymerase. Science 239, 487-491.

Sambrook, J., Fritsch, E. F. \& Maniatis, T. (1989). Molecular Cloning : a Laboratory Manual, 2nd edn. Cold Spring Harbor, NY: Cold Spring Harbor Laboratory.

Sipe, A. R., Wilbur, A. E. \& Cary, S. C. (2000). Bacterial symbiont transmission in the wood-boring shipworm Bankia setacea (Bivalvia: Teredinidae). Appl Environ Microbiol 66, 1685-1691.

Stackebrandt, E. \& Goebel, B. M. (1994). Taxonomic note: a place for DNA-DNA reassociation and $16 \mathrm{~S}$ rRNA sequence analysis in the present species definition in bacteriology. Int $J$ Syst Bacteriol 44, 846-849.

Swofford, D. L. (1997). PAUP* 4.0 (Phylogenetic Analysis Using Parsimony). Sunderland, MA: Sinauer.

Waterbury, J. B., Calloway, C. B. \& Turner, R. D. (1983). A cellulolytic-nitrogen fixing bacterium cultured from the Gland of Deshayes in shipworms (Bivalvia: Teredinidae). Science 221, 1401-1403. 